\title{
The role of radiological imaging in the diagnosis of acute appendicitis
}

\author{
E Albiston MD
}

T Albiston. The role of radiological imaging in the diagnosis of acute appendicitis. Can J Gastroenterol 2002;16(7):451-463.

Several strategies have been employed to improve the accuracy of the diagnosis of appendicitis and to reduce the associated perforation rate. Because clinical algorithms have been disappointing, many physicians resort to radiological modalities. Plain abdominal x-rays are nonspecific, barium enema examination has relatively low accuracy, scintigraphy scans require considerable time and are difficult to interpret, and magnetic resonance imaging is relatively unstudied. The most promising modalities are graded compression sonography and computed tomography. In expert hands, these techniques can achieve a high degree of accuracy. Nevertheless, most published studies have been marred by methodological difficulties. Moreover, ultrasound is more useful in detecting than in ruling out appendicitis. The radiological criteria for acute appendicitis, the accuracy of various imaging modalities and the limitations of the available research are described.

Key Words: Appendicitis; Computed tomography; Diagnosis; Magnetic resonance imaging; Scintigraphy; Ultrasonography

\section{Le rôle de l'imagerie radiologique dans le diag- nostic d'appendicite aiguë}

RÉSUMÉ : Plusieurs stratégies ont été utilisées pour améliorer la précision du diagnostic d'appendicite et réduire le taux de perforation connexe. Puisque les algorithmes cliniques se révèlent décevants, de nombreux médecins ont recours à des modalités radiologiques. Les rayons-X simples de l'abdomen ne sont pas spécifiques, les examens au lavement baryté présentent une précision relativement faible, la scintigraphie est très longue à exécuter et difficile à interpréter et l'imagerie par résonance magnétique est relativement non étudiée. Les modalités les plus prometteuses sont la sonographie avec compression dosée et la tomodensitométrie. Exécutées par des mains expertes, ces techniques peuvent assurer un taux de précision élevé. Néanmoins, la plupart des études publiées sont gâchées par des problèmes méthodologiques. De plus, les ultrasons sont plus utiles pour déceler l'appendicite que pour en écarter la possibilité. Les critères radiologiques d'appendicite aiguë, la précision des diverses modalités d'imagerie et les limites des recherches disponibles sont décrits. 
ppendicitis is a common and important clinical probAlem that afflicts $8.6 \%$ of male and $6.7 \%$ of female Americans. There are 250,000 to 300,000 appendectomies, including 60,000 to 80,000 involving children, and more than one million patient-days of hospitalization for appendicitis, each year in the United States (1-3).

There are problems with the current methods of diagnosis, which are based mainly on the clinical history, physical examination and simple laboratory tests. The classic presentation includes vague midabdominal pain, anorexia and nausea, followed by localized right lower quadrant (RLQ) abdominal pain and guarding, and leukocytosis. Up to 45\% of cases, however, have atypical symptoms and/or signs (4).

The clinical diagnosis of acute appendicitis is accurate only $70 \%$ to $80 \%$ of the time (5-9). Delays in diagnosis often lead to perforation $(5,10,11)$, which occurs in $8 \%$ to $39 \%$ of cases $(2,7,8,12-14)$. To prevent perforation, the surgeon may adopt liberal criteria for surgery, which results in negative appendectomy rates of $15 \%$ to $22 \%(7,9,15)$. Unnecessary surgery causes pain and inconvenience for patients, wastes precious health care resources and can lead to serious complications (15-17). Appendicitis is especially difficult to diagnose, and the consequences of error are greater in children, pregnant women and elderly patients (18-23). These difficulties are due to physiological factors, variations in clinical presentation and, in some cases, problems with communication.

Most surveys have found an inverse relationship between rates of perforation and rates of negative appendectomy $(1,7,24-26)$. Therefore, attempts to reduce the rate of unnecessary surgery often lead to unacceptable perforation rates, while a reduction in the latter is generally achieved at the expense of diagnostic accuracy. For example, Law et al (13) reviewed 216 patients with a preoperative diagnosis of appendicitis, and reported a high rate of diagnostic accuracy (89\%), together with a high perforation rate (29\%). In contrast, Andersen et al (14) reviewed 454 patients and reported a much lower perforation rate $(8 \%)$ at the expense of a lower accuracy rate $(67 \%)$.

This dilemma has been addressed in four ways:

- adoption of standardized diagnostic criteria;

- observation in hospital of patients with equivocal clinical presentations;

- application of diagnostic tests, including radiological imaging; and

- use of diagnostic laparoscopy.

Of the many standardized scoring systems for the diagnosis of acute appendicitis, the Alvarado criteria (27), which generate the MANTRELS score (Table 1), appear to be the most effective (28). A score of more than seven points has a relatively high sensitivity ( $88 \%$ to $90 \%$ ), but the specificity is generally no better than $80 \%$, and is especially low in women (28-30). Modifications have included removing the leukocyte count criteria or reducing the threshold to five points, but these modifications further
TABLE 1

Alvarado scoring system

\begin{tabular}{lc}
\hline Clinical or laboratory feature & Points \\
\hline $\begin{array}{l}\text { Migration of pain from the midabdomen to } \\
\text { right lower quadrant }\end{array}$ & 1 \\
$\begin{array}{l}\text { Anorexia or acetonuria (a surrogate } \\
\text { marker of food avoidance) }\end{array}$ & 1 \\
Nausea and vomiting & 1 \\
Tenderness in the right lower quadrant & 2 \\
Rebound tenderness & 1 \\
Elevated temperature $\left(\geq 38^{\circ} \mathrm{C}\right)$ & 1 \\
Leukocytosis (>10,400 cells $\left./ \mathrm{mm}^{3}\right)$ & 2 \\
Shifted white blood cell count $(>75 \%$ neutrophils) & 1 \\
Total possible points & 10
\end{tabular}

Data from reference 27

impair the specificity of the system, particularly in pediatric patients (29-32). While these and other criteria may assist junior staff and nonsurgical personnel in identifying patients with appendicitis, they are not likely to be helpful for experienced surgeons who possess astute clinical judgement.

Several authorities have suggested that close observation of patients with atypical presentations improves diagnostic accuracy without causing inordinate delays in treatment $(9,33,34)$. Early, appropriate referral to a surgeon appears to be the most important way of producing a successful outcome.

With the exception of leukocytosis, laboratory markers of inflammation have not proved to be of much value in early diagnosis. The use of radiological imaging techniques - plain x-rays, barium enema, ultrasonography, computed tomography (CT), nuclear imaging (scintigraphy) and magnetic resonance imaging $(\mathrm{MRI})-$ is the subject of this review.

Several groups advocate the use of diagnostic laparoscopy (35-39). It has a high sensitivity and specificity, and may be especially valuable in women of child-bearing age, because gynecological diseases that might be confused with appendicitis can be readily diagnosed. Appendectomy can be carried out safely and quickly with this technique (40-43). The normal-appearing appendix can be left in situ, thus reducing the rate of negative appendectomy $(35,39,41-46)$. Some authorities recommend that the appendix be removed in all cases, however, because a normal macroscopic appearance does not exclude the presence of histological appendicitis with certainty (47-49). Moreover, it has been suggested that recurrent pain can arise from appendices that have neurochemical or immunological abnormalities even in the absence of overt inflammation (50-56).

A substantial proportion of patients report a history of recurrent episodes of pain before appendectomy (recurrent appendicitis) or of prolonged pain, which may or may not 
be accompanied by histological evidence of fibrosis or of chronic inflammation (chronic appendicitis) (57-66).

\section{PLAIN ABDOMINAL X-RAYS}

Except for the presence of an appendicolith (fecalith) and possibly of a sentinel loop, the findings of acute appendicitis on plain radiographs (Table 2) are nonspecific and generally appear only in advanced disease (67-70). Appendicolithiasis is said to be the most specific of the common findings of appendicitis but is identified in only $10 \%$ to $15 \%$ of all cases $(71,72)$ - a considerably lower rate than those quoted in studies of ultrasonography and CT (vide infra). Plain $\mathrm{x}$-rays are thus of little value in the early diagnosis of appendicitis $(70,73-75)$ and are actually less cost effective than either ultrasonography or CT $(76,77)$. They are more helpful in detecting nonappendiceal causes of acute abdominal pain, including bowel obstruction, ureteral calculi and basal pneumonia (78).

\section{BARIUM ENEMA}

The diagnosis of acute appendicitis by barium enema examination is based on nonfilling of the inflamed appendix and on the presence of an extrinsic defect in the wall of the cecum, due to appendiceal and periappendiceal inflammation (79). The examination can result in complications, however, including perforation $(79,80)$, and its diagnostic accuracy is variable and often poor (81-83). Technical failures occur in $16 \%$ of examinations; $10 \%$ to $23 \%$ of normal appendices fail to fill, and up to $20 \%$ of inflamed but nongangrenous appendices fill completely $(82,84-86)$. It may be difficult to be certain that the entire appendix, including its bulbous tip, has been filled (87). Therefore, cases of distal appendix, in which the proximal part of the organ could be opacified, might easily be missed (88). Diagnostic confusion can also occur in patients with chronic or recurrent appendicitis $(79,89,90)$.

\section{ULTRASONOGRAPHY}

The usefulness of ultrasonography in the diagnosis of appendicitis has been known since the early 1980s. It is safe (including during pregnancy) and relatively inexpensive, and can be performed quickly and repeatedly, using portable equipment. The patient can indicate the point of maximal tenderness, to which the transducer can be applied. This can facilitate the diagnosis when the appendix is in an atypical location. Children, because of the relative paucity of intra-abdominal fat, and young women, who are susceptible to gynecological disorders, are especially good candidates for sonography.

Sonography has, however, several limitations. Some of the limitations are nonspecific: obesity, intestinal gas, patient cooperation, quality of equipment, and the skill and experience of the technician. Other limitations are particularly relevant to acute appendicitis (Table 3).

Some of these limitations have been circumvented by using graded compression, a technique by which the transducer is applied with gradually increasing pressure to the
TABLE 2

Findings on plain x-ray of acute appendicitis

Appendicolithiasis

Air in the appendix, especially if surrounding an appendicolith

Soft tissue mass in the right lower quadrant

Extraluminal air bubbles (double lucency sign) or air-fluid levels in the right lower quadrant

Air-fluid levels in or dilation of the terminal ileum ('sentinel loop')

Blurring of the psoas shadow

Free air in the peritoneum or dissecting into the retroperitoneal planes

Localized ileus

Rightward scoliosis of the lumbar spine

Data from references $67-70$

\section{TABLE 3 \\ Limitations of sonography in the diagnosis of acute appendicitis}

Dilation of loops of bowel in the right lower quadrant can obscure

the inflamed appendix

The inflamed appendix can be difficult to distinguish from the terminal ileum

The patient may not tolerate application of the transducer to the painful area

The transducer may not have enough spatial resolution to visualize such a small structure as the early inflamed appendix

area of McBurney's point. Continuous, steadily increasing pressure from the transducer, unlike intermittent application of the device, is tolerated relatively well by patients with acute appendicitis (91). Gas artifacts are reduced, because the transducer either compresses or displaces uninflamed loops of bowel. Specifically, compression can expel intraluminal contents from the normal appendix, but not if it is distended and thickened due to inflammation. This technique also brings the transducer closer to the area of the appendix, which allows the use of high-frequency transducers with short focal ranges (such as 5.0 or $7.5 \mathrm{MHz}$ linear-array transducers).

Obesity is still a major problem for sonography. Because it is difficult to approximate the transducer to the appendix, low-frequency transducers (which have long focal ranges but poor resolution) must be used, and it is difficult to apply sufficient pressure to compress the bowel adequately. Furthermore, cases of retrocecal appendicitis can easily be overlooked because of the inability to see through the cecum. Special techniques, such as oblique imaging from a laterally placed transducer (92), may be required in such cases. Pelvic (transvaginal) sonography is also helpful in distinguishing appendicitis from gynecological disorders, especially if transabdominal approaches are inconclusive $(93,94)$. Disease is confined to the tip of the appendix (dis- 
TABLE 4

Prospective studies of sonography in the diagnosis of acute appendicitis

\begin{tabular}{|c|c|c|c|c|c|c|c|}
\hline Author, year (reference) & $\mathbf{n}$ & $\begin{array}{c}\text { Acute } \\
\text { appendicitis (\%) }\end{array}$ & $\begin{array}{c}\text { Sensitivity } \\
(\%)\end{array}$ & $\begin{array}{c}\text { Specificity } \\
(\%)\end{array}$ & $\begin{array}{l}\text { PPV } \\
(\%)\end{array}$ & $\begin{array}{l}\text { NPV } \\
(\%)\end{array}$ & $\begin{array}{c}\text { Accuracy } \\
(\%)\end{array}$ \\
\hline Puylaert et al, 1987 (103) & 60 & 47 & 89 & 100 & 89 & 91 & 95 \\
\hline Abu-Yousef et al, 1987 (99) & 68 & 37 & 80 & 95 & 91 & 89 & 90 \\
\hline Jeffrey et al, 1988 (104) & 250 & 36 & 90 & 96 & 93 & 94 & 94 \\
\hline Vignault et al, $1990(207)^{*}$ & 70 & 47 & 94 & 89 & 89 & 94 & 91 \\
\hline Schwerk et al, 1990 (140) & 857 & 23 & 90 & 98 & 94 & 97 & 96 \\
\hline Davies et al, 1991 (138) & 152 & 27 & 96 & 94 & 96 & 94 & 95 \\
\hline Rioux, 1992 (208) & 170 & 26 & 93 & 94 & 86 & 98 & 94 \\
\hline Sivit et al, $1992(141)^{\star}$ & 180 & 29 & 88 & 82 & 90 & 79 & 86 \\
\hline Chen et al, 1998 (209) & 191 & 75 & 99 & 68 & 90 & 97 & 92 \\
\hline Hahn et al, $1998(114)^{\star}$ & 3859 & 13 & 90 & 97 & 82 & 98 & 96 \\
\hline Schulte et al, $1998(210)^{*}$ & 1285 & 9 & 92 & 98 & 90 & 98 & 98 \\
\hline Sivit et al, $2000(158)^{*}$ & 315 & 26 & 78 & 93 & 79 & 92 & 89 \\
\hline Douglas et al, 2000 (125) & 129 & 46 & 95 & 89 & 88 & 95 & 91 \\
\hline
\end{tabular}

*Studies comprised exclusively pediatric patients (other studies comprised mainly adults). NPV Negative predictive value; PPV Positive predictive value

tal appendicitis) in 5\% to $8 \%$ of cases, and can be missed if the entire length of the appendix is not visualized (95-97).

In most normal appendices, ultrasonography can demonstrate an echogenic layer (arising from the submucosa) surrounded by a hypoechoic layer (the muscularis propria) (95). In some cases, additional luminal, epithelial, subepithelial and serosal structures can be identified and give rise to a 'target' appearance. The definition of these layers, especially that of the echogenic submucosal layer, is lost with transmural extension of edema, inflammatory infiltrate and necrosis $(95,98)$. The normal appendix resembles the terminal ileum sonographically, except that the former generally lacks peristalsis, has a blind end, is less than $6 \mathrm{~mm}$ in diameter, is round instead of oval in cross-section, and does not change in configuration with time (92).

The key sonographic finding of acute appendicitis is a dilated and noncompressible appendix with a thickened wall. An appendicolith, which can be identified by its acoustic shadow, is found in up to $29 \%$ to $36 \%$ of cases (95). The loss of the submucosal echogenic layer, as well as the presence of hyperechoic periappendiceal fat and of a loculated pericecal fluid collection, are said to be indicative of perforation (99-101). The inflamed appendix is less likely than the normal appendix to contain luminal air (102). Mesenteric lymphadenopathy is sometimes apparent but can be confused with mesenteric adenitis in children $(91,95,100)$. Most authorities have stated that the normal appendix can be visualized by ultrasonography less than $5 \%$ of the time (103-105); therefore, it is easier to establish the diagnosis of appendicitis than to exclude it.

There has been considerable discussion about appendiceal diameter, the most widely used diagnostic criterion. Most authorities use a threshold of 6 or $7 \mathrm{~mm}$ for appendicitis $(91,95,98,99,101,104,106,107)$, and dilation is often quite obvious (108). A dilated appendix is not, however, a specific sign of appendicitis (109), because the healthy appendix can dilate in the presence of metabolic disturbances or inflammatory processes elsewhere in the abdomen or pelvis. An appendiceal wall diameter of $3 \mathrm{~mm}$ or greater may be more predictive, but effacement of the wall of a very dilated appendix may occur just before rupture $(97,98,110)$. Moreover, a dilated noncompressible appendix is much less frequently seen after perforation $(101,111)$, probably because of collapse or even disintegration. For this reason, sonography is actually less able to detect perforated than nonperforated acute appendicitis, although the recent use of more refined techniques has partially overcome this problem $(103,111-114)$.

Many investigators have studied the diagnostic accuracy of ultrasonography for patients suspected of having appendicitis. Some of the largest and best designed of the prospective studies are summarized in Table 4. In most cases, graded compression technique was used, but the use of pelvic ultrasonography was usually not discussed specifically. Diagnostic accuracy seems to be similar in women and men $(98,115)$, although most investigators have not reported their results separately according to sex. It is also accurate in pregnant women (116). Comparable performance characteristics are observed with adult and pediatric patients (Table 4), but it is less sensitive in patients with a body mass index of 25 or greater than in lean patients $(107,117)$.

Some investigators have stated that ultrasonography is more accurate than clinical assessment in diagnosing acute appendicitis (118-123), while others have found that it offers no advantage $(110,124)$. It has been suggested that the use of ultrasonography would reduce the negative appendectomy rate to $7 \%$ or even lower, but the perforation rate is not decreased $(78,110,111,113,119,125-128)$. Many studies may have been biased in favour of sonography. The radiological tests were performed after the initial clinical 
assessment with which they were compared, and thus after the illness had progressed. Not all patients underwent surgery, and it was not always clear that the ultrasound results did not influence the decision to operate. These factors introduce possible verification bias. The interactive nature of sonography could also have introduced additional biases, in that patients with localized pain and tenderness (ie, those with a high pretest probability of a surgical condition) would be more likely to have a definitive ultrasonography result than those without localizing symptoms or signs $(129,130)$.

Ultrasonography was generally performed and interpreted by experts in the field, whereas clinical assessments were often performed by junior surgeons, surgical residents or others using clinical scoring systems $(118,123,124,128,131)$. Sonography is highly dependent on technical expertise and the nature of the equipment, however, and it is unlikely to perform as well in nonspecialized centres as in research centres $(92,132-136)$.

A shortcoming that is common to all of these investigations is the failure either to apply strict histological criteria for the diagnosis of appendicitis or to estimate the interobserver variability for pathologists or for the radiologists. Variability in the histological criteria can affect the sensitivity and specificity of the tests (137). Moreover, entry criteria are often vague, and patients with a wide range of pretest likelihood of having acute appendicitis may be included.

Most surgeons urgently operate on patients with typical clinical findings of appendicitis, and do not appreciate the delay caused by obtaining a sonogram $(125,127,138,139)$. It appears that a substantial minority ( $8 \%$ to $26 \%$ ) of patients with clinically typical appendicitis have false-negative ultrasonography scans $(113,127,140-143)$. Sonography may be more useful in equivocal cases. Orr et al (144) undertook a meta-analysis of 17 studies (including 3358 patients) published between 1986 and 1995, and categorized patients according to their likelihood of appendicitis - high, intermediate and low (with disease prevalences of $80 \%, 40 \%$ and 2\%, respectively). They found that, in the high-risk group, the positive predictive value of ultrasonography was $97.6 \%$ but the negative predictive value was only $59.5 \%$; in the low risk group, on the other hand, the negative predictive value was $99.7 \%$ but the positive predictive value was only $19.5 \%$. They concluded that sonography was most useful for patients with intermediate clinical risk of appendicitis. Other investigators have found that ultrasonography is cost effective only for patients with equivocal clinical findings (145-147).

Another fundamental weakness of most ultrasonography studies is the failure to address inconclusive test results adequately. Sometimes, the failure to visualize the appendix is regarded as evidence against the diagnosis of appendicitis (110); however, this assumption may not be valid. In other studies, inconclusive results (such as an appendix of 5 to $7 \mathrm{~cm}$ in diameter) lead to further radiological investigation (eg, CT scanning or Doppler ultrasonography). It would be preferable if investigators acknowledged the proportion of indeterminate tests. In one study, the kappa scores for intraand interobserver variability among radiologists were only 0.39 to 0.42 and 0.15 to 0.20 , respectively (148).

Another problem occurs when the sonogram suggests the presence of appendicitis (ie, a dilated, noncompressible appendix), but the patient's illness resolves spontaneously $(97,111,149,150)$. Are these cases of self-limited acute appendicitis, or do they represent false-positive ultrasonography results? Such patients generally are not subjected to immediate surgery, although some have further episodes of pain and ultimately undergo appendectomy. It has been suggested that the risk of eventual recurrence is higher in patients with previous episodes of typical pain and in those with appendicolithiasis (149). When surgery is not performed in patients who have undergone radiological investigation, it is crucial for the investigator to ensure sufficient follow-up to detect cases of recurrent or chronic appendicitis. Studies vary in the extent to which this has been done. Even if symptoms do not recur, the failure to operate on all patients with positive (or negative) scans interferes with the ability to determine the true sensitivity and specificity of the imaging modality.

\section{COLOUR DOPPLER SONOGRAPHY}

Colour Doppler ultrasonography identifies areas of hypervascularity in the wall of the inflamed (but not the normal) appendix and in the wall of a periappendiceal abscess, and may be helpful if the appendix has a diameter of 5 to $7 \mathrm{~mm}$ (151-154). The absence of either a visible appendix or strong Doppler signals is said to be strong evidence against the diagnosis of acute appendicitis (155). Doppler signals may not be detectable, however, if gangrenous appendicitis supervenes (152). This technique can also reveal other inflammatory and even neoplastic conditions in the abdomen and pelvis, some of which can cause false-positive results on conventional (gray scale) ultrasonography scans (151). Doppler ultrasonography is slightly more accurate than conventional techniques, although the differences may not be clinically significant (156). A further refinement, power Doppler sonography, may more precisely evaluate local blood flow (157), but some authorities question its benefit (92).

\section{CT}

The past decade has witnessed the increasing use of CT in the assessment of patients with acute appendicitis. Advantages of CT over ultrasonography include enhanced ability to detect the normal appendix (and thus rule out the diagnosis of appendicitis), appendicoliths (especially when using helical CT), retrocecal appendicitis, perforation and its complications, and alternative diagnoses. Disadvantages are the increased cost of CT; the use of ionizing radiation; the frequent need for contrast material; and the time required to prepare the patient, and to perform and interpret the scan. Unlike ultrasonography, CT is more effective for obese patients. Overall, the diagnostic accuracy of CT is 
TABLE 5

Prospective studies of computed tomography scans in the diagnosis of acute appendicitis

\begin{tabular}{|c|c|c|c|c|c|c|c|c|}
\hline $\begin{array}{l}\text { Author, } \\
\text { year (reference) }\end{array}$ & $\begin{array}{l}\text { Contrast } \\
\text { agent }\end{array}$ & $\mathbf{n}$ & $\begin{array}{c}\text { Acute } \\
\text { appendicitis (\%) }\end{array}$ & $\begin{array}{l}\text { Sensitivity } \\
\text { (\%) }\end{array}$ & $\begin{array}{c}\text { Specificity } \\
(\%)\end{array}$ & $\begin{array}{l}\text { PPV } \\
(\%)\end{array}$ & $\begin{array}{l}\text { NPV } \\
(\%)\end{array}$ & $\begin{array}{c}\text { Accuracy } \\
(\%)\end{array}$ \\
\hline Balthazar et al, 1991 (176) & Oral, intravenous & 100 & 64 & 98 & 83 & 91 & 97 & 93 \\
\hline Malone et al, 1993 (168) & None & 211 & 36 & 87 & 97 & 94 & 93 & 93 \\
\hline Balthazar et al, 1994 (115) & Oral & 100 & 54 & 96 & 89 & 96 & 95 & 94 \\
\hline Rao et al, 1997 (211) & Oral, rectal & 100 & 56 & 100 & 95 & 97 & 100 & 98 \\
\hline Rao et al, 1997 (212) & Rectal & 100 & 53 & 98 & 98 & 98 & 98 & 98 \\
\hline Lane et al, 1997 (213) & None & 109 & 38 & 90 & 97 & 95 & 95 & 94 \\
\hline Funaki et al, 1998 (214) & Oral, rectal & 100 & 30 & 97 & 94 & 88 & 99 & 95 \\
\hline Lane et al, 1999 (215) & None & 300 & 38 & 96 & 99 & 98 & 97 & 97 \\
\hline Pickuth et al, 2000 (161) & None & 120 & 78 & 95 & 89 & 97 & 83 & 93 \\
\hline Sivit et al, 2000 (158) & Oral, rectal & 153 & 40 & 95 & 93 & 91 & 97 & 94 \\
\hline Weltman et al, 2000 (173) & Oral, intravenous & 100 & 48 & 99 & 98 & 98 & 99 & 99 \\
\hline Stroman et al, 2001 (159) & Oral, intravenous & 107 & 37 & 92 & 85 & 75 & 95 & 90 \\
\hline Jacobs et al, 2001 (172) & Oral, intravenous & 228 & 22 & 94 & 95 & 84 & 98 & 95 \\
\hline
\end{tabular}

NPV Negative predictive value; PPV Positive predictive value

superior to that of ultrasonography $(115,158-161)$, and CT is often able to establish the diagnosis when sonography is inconclusive $(162,163)$. Radiologists generally have more confidence in CT $(148,164)$, and surgeons are more likely to trust a negative $\mathrm{CT}$ than a negative ultrasonography result (162). There is less dependence on operator technique, and the images are more easily interpreted by trainees, by radiologists without special training and even by clinicians.

Some of the criteria for the diagnosis of appendicitis with the use of CT are similar to those for diagnosis with the use of ultrasonography, including appendiceal dilation, wall thickening and appendicolithiasis. Periappendiceal changes are more readily identified by CT and include blurred pericecal fat, mesenteric fat stranding, phlegmon, abscess, abnormal collections of air and fluid accumulations (165-167). Inflammatory thickening of the wall of the cecum is also often seen, and gives the appearance of an arrowhead or of a 'cecal bar' when the cecum is opacified by contrast material.

It is not possible to assess the compressibility or motility of the appendix, but the ability of the appendix to fill with enteric contrast material can be evaluated by CT. This is most rapidly and effectively done using rectal contrast agents. The alternative use of oral contrast material is more time consuming (by at least 30 to $60 \mathrm{~min}$ ) and is limited by nausea, vomiting and disturbance of gastrointestinal motility. Failure to use enteric contrast material substantially reduces the ease of interpretation of the images, because the inflamed appendix might easily be mistaken for a loop of distal ileum. The use of intravenous contrast material introduces more risk, but it can reveal increased blood flow in the wall of the inflamed appendix or in periappendiceal tissues, and may be especially useful in thin patients (whose internal organs are not well separated by abdominal fat) and in those with periappendiceal abscesses. The relative merits of various contrast materials have been extensively debated (92,168-172).

Accuracy in evaluating the appendix can be enhanced if $5 \mathrm{~mm}$ instead of $10 \mathrm{~mm}$ sections are taken during scanning - a procedure known as thin collimation (173). Scanning times can be reduced by narrowing the field to the area of the appendix alone. This technique, called focused appendiceal CT (FACT), may, however, miss disease elsewhere in the abdomen or pelvis, or even atypically situated appendices. Therefore, quick preliminary scanning of the abdomen and pelvis is recommended, together with rectal instillation of contrast material (171). The best results have been obtained using helical CT, a technique that is costly and is available at only a small minority of radiology facilities (174). Advantages include the high speed of the technique, which allows rapid scanning of relatively large areas (even with thin collimation) and a reduction in image distortion due to respiration, but the images are somewhat less sharp than those obtained with conventional techniques (175).

Some of the largest and most well designed prospective studies of CT in acute appendicitis are summarized in Table 5. Most have employed helical CT with thin collimation, enhanced by rectal and/or oral contrast agents. Only one of the studies described in Table 5 did not use helical CT (176). Retrospective studies have yielded similar results $(177-181)$. It is difficult to find differences between performance characteristics of helical and conventional CT in these studies. A study that directly compared these techniques seemed to reveal a significant advantage for helical CT, but there was wide and uncontrolled variation in other aspects of the scanning technique (163). It has been claimed that CT is more accurate than clinical assessment $(163,182)$, and that it reduces the negative laparotomy rate 


\begin{tabular}{|c|c|c|c|c|c|c|c|}
\hline Author, year (reference) & $\mathbf{n}$ & $\begin{array}{c}\text { Acute } \\
\text { appendicitis (\%) }\end{array}$ & $\begin{array}{c}\text { Sensitivity } \\
(\%)\end{array}$ & $\begin{array}{c}\text { Specificity } \\
(\%)\end{array}$ & $\begin{array}{l}\text { PPV } \\
(\%)\end{array}$ & $\begin{array}{l}\text { NPV } \\
(\%)\end{array}$ & $\begin{array}{c}\text { Accuracy } \\
(\%)\end{array}$ \\
\hline Foley et al, 1992 (216) & 30 & 63 & 81 & 100 & 100 & 73 & 89 \\
\hline Evetts et al, 1994 (217) & 37 & 73 & 85 & 93 & 96 & 69 & 89 \\
\hline Kao et al, 1996 (218) & 50 & 60 & 93 & 90 & 92 & 93 & 90 \\
\hline Lin et al, 1997 (219) & 49 & 51 & 92 & 92 & 92 & 92 & 92 \\
\hline Rypins and Kipper, 1997 (220) & 100 & 37 & 97 & 94 & 90 & 98 & 95 \\
\hline Kipper, 1999 (221) & 124 & 41 & 98 & 82 & 82 & 98 & 90 \\
\hline
\end{tabular}

NPV Negative predictive value; PPV Positive predictive value

without increasing the perforation rate (183-186). It also seems to have a greater positive impact on clinical care than does ultrasonography $(115,162,186,187)$. Another study, however, found that CT scanning significantly prolonged the diagnostic evaluation and increased the perforation rate (188).

Many of the methodological deficiencies that have been described in ultrasonography studies also apply to CT studies. For example, strict histological criteria have not been employed, not all patients underwent surgery, CT was compared with initial (and not later) clinical assessment and most studies were carried out by a relatively small number of enthusiastic radiologists. One study found that only $5 \%$ of CT scan results were not definitive, but many of the patients had prolonged symptoms and presumably fairly advanced disease (182). A different conclusion was reached by other investigators, however, who found that $12 \%$ of CT scans were interpreted as equivocal (189). The proportion of nondiagnostic results might actually increase if the decision to operate were based predominantly on the results of CT scans, as some investigators have advocated $(182,190)$.

One study found a relatively low agreement between radiologists in the interpretation of helical CT scans with $5 \mathrm{~mm}$ and $10 \mathrm{~mm}$ collimation (kappa values were 0.58 and 0.69 , respectively) (173). In another study, the kappa statistics for intraobserver and interobserver variability were only 0.76 and 0.36 , respectively, for FACT without contrast and only 0.85 and 0.45 , respectively, for FACT with rectally administered contrast (148).

Several groups have evaluated the cost effectiveness of CT scanning. The results of such an analysis depend on the relative costs of the test itself, hospital admission, surgery and care of patients with complications, and may not be easily translated across jurisdictions. Garcia Peña et al (191) undertook a decision analysis based on a retrospective review of 609 cases over 20 months, and found that a policy of performing helical CT (with oral and intravenous contrast), followed by observation in hospital, would be the most cost effective in the management of children with intermediate clinical likelihood for appendicitis. The brief admission to hospital would reduce the rate of missed appendicitis and thus reduce the expenses related to the treatment of complications. The authors recommended immediate surgery for patients with classic symptoms. The same group also found that ultrasonography, followed by $\mathrm{CT}$ in equivocal cases, was more cost effective than clinical assessment alone (192).

Rao et al (182) and Rhea et al (190) have argued that cost savings can be realized by performing FACT with rectal contrast in patients with an estimated high likelihood of appendicitis, because a significant minority of these patients would otherwise undergo negative appendectomies. These arguments assume that a high degree of accuracy (in the range of 98\%) can be achieved with CT, and that all patients with radiological signs of appendicitis actually require surgery, rather than have self-limited disease. This latter assumption may not be valid. Moreover, CT scanning must be performed and interpreted rapidly and definitively (they report a total time from request to final report of less than $1 \mathrm{~h}$ ); otherwise the perforation rate is likely to increase.

\section{NUCLEAR IMAGING}

Nuclear imaging techniques detect accumulations of white blood cells (or of immunoglobulins) in areas of inflammation. Other causes of RLQ inflammation are also detected, not all of which require surgery. Disease in atypical locations can be detected but may be misdiagnosed. Because the liver, spleen, bone marrow and large blood vessels take up radionuclide, the scans are limited in their anatomic scope. The available techniques differ in the length of time required for a positive scan and in the need for preliminary in vitro labelling of the patient's leukocytes.

Due to the availability and relatively low cost of the isotope, ${ }^{99} \mathrm{~m}_{\text {technetium-labelled hexamethylpropylene amine }}$ oxime (HMPAO) scans are most commonly performed. A $2 \mathrm{~h}$ preparation time is required, during which the patient's blood is labelled with the radionuclide before the scan can be commenced. Scanning is then undertaken for up to $3 \mathrm{~h}$, although most positive results occur before then. The per- 
formance characteristics of this technique have been calculated in several studies (Table 6), but these impressive results may not be easily achieved in nonspecialized centres, because of difficulty in interpreting the images. Although the studies summarized in Table 6 found that the accuracy of this technique was similar in all demographic groups, another team reported poor results in children, as well as poor interobserver agreement in the interpretation of

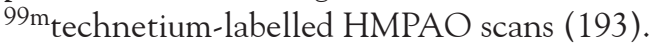

A newer technique involves in vivo targeting of leukocytes by a specific antileukocyte antibody (anti-CD15 immunoglobulin M monoclonal antibody, or LeuTech [Palatin Technologies, USA) that is labelled with ${ }^{99} \mathrm{~m}_{\text {technetium. }}$ Thus, no preparatory time is required. Furthermore, most positive images are apparent within $15 \mathrm{~min}(194,195)$. The two published trials of this technique $(194,195)$ came from the same institution, and found that the sensitivities were close to $100 \%$, but the specificities were only $83 \%$ to $84 \%$ when approximately one-half of the study patients had appendicitis.

Other radiolabelled antigranulocyte antibodies have also been investigated but do not seem to be superior to

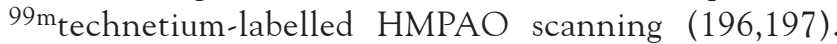
Immunoglobulin $\mathrm{G}$ antibody scans may offer more promise, but only the results of preliminary trials have been reported $(198,199)$. Other scintigraphic modalities have been studied, but they have been limited by prolonged preparation times, inferior sensitivity and/or specificity, high frequencies of uninterpretable images or high cost of the radionuclide (200-203).

\section{MRI}

The MRI diagnosis of acute appendicitis is generally based on the demonstration of an abnormal appendix (204). The presence of periappendiceal fluid collections, appendiceal phlegmon, pericecal inflammatory changes or abscesses (with or without visualization of an inflamed appendix) signifies perforation. The appendix is often curved, and thus may be seen as two round structures on a given image. Specific findings and technical details have been described $(204,205)$. In the only two studies that have assessed its diagnostic accuracy, MRI seemed to be superior to ultrasonography, especially in cases of retrocecal and pelvic appendicitis, in obese patients and if perforation had occurred $(204,205)$. In one study, however, MRI (unlike ultrasonography) was performed only in patients with appendicitis (205). Because the normal appendix cannot be identified with the use of MRI, the diagnosis of appendicitis cannot easily be excluded. Moreover, appendicoliths cannot be distinguished from air bubbles or avascular zones. Even though this modality is operator-independent, radiological expertise in assessing the appendix by MRI is limited. Other disadvantages of this technique are its high cost, the relatively long time needed for the examination, the need for intravenous contrast material (in some applications), the need to immobilize the patient (which might be problematic when dealing with children) and difficulties with claustrophobic patients. It is, therefore, unlikely that MRI will supplant ultrasonography or CT as the preferred imaging modality for the diagnosis of appendicitis.

\section{SUMMARY}

The timely diagnosis of acute appendicitis is still mainly determined by the clinical acumen of attending physicians and surgeons. Diagnostic algorithms - including scoring systems, leukocyte counts and radiological imaging - may have adjunctive roles. Patients with classical clinical presentations should be operated on urgently, without resorting to prior imaging, unless complications that might affect the course of surgery are suspected. Plain abdominal radiographs are of little value, except if certain nonappendiceal disorders are considered likely. Barium enema examinations are cumbersome and have been supplanted by cross-sectional imaging techniques. Nuclear imaging has been disappointing, because most techniques require long periods of time and the scans are often indeterminate. MRI remains unproven, and resources are unlikely to be readily available for this indication.

Ultrasonography is safe and relatively inexpensive. Good diagnostic accuracy can be achieved by expert personnel who employ graded compression, but the technique is highly dependent on the skill, experience and persistence of the operator. It may be especially useful when evaluating children (because of their low body mass) and women (because of their proclivity to gynecological disorders). The inability to identify the normal appendix, and the high false-negative rate in retrocecal appendicitis are important drawbacks. Its sensitivity is too low for it to be of value in patients who are clinically likely to have appendicitis, but it does seem to be beneficial in equivocal cases. Colour Doppler ultrasonography may offer a small advantage when conventional techniques yield inconclusive results.

CT is highly accurate, especially when conducted by experienced personnel. Highly refined techniques, such as helical CT, thin collimation and the use of rectal contrast, seem to enhance its effectiveness. It is superior to ultrasonography in obese patients and in those with perforation or other complications. Because the normal appendix can usually be identified, appendicitis can be ruled out with more confidence. For it to be valuable as a diagnostic technique without causing important delays in management, however, the equipment and specialized radiology staff need to be continuously available.

Unfortunately, studies of radiological techniques in acute appendicitis have been marred by the lack of standardized radiological or even histological criteria for the diagnosis of appendicitis. There are also methodological limitations, including comparison of imaging with initial clinical assessments, lack of blinding, failure to confirm (either by surgery or by thorough and prolonged follow-up) the diagnosis in all patients, lack of acknowledgement of indeterminate test results and failure to measure interobserver variability. Finally, most studies have been conducted by investigators with a high degree of interest and expertise 
in appendiceal imaging. The applicability of their results to other settings is unclear.

Some investigators have reported very high degrees of diagnostic accuracy with advanced radiological techniques, such as graded compression ultrasonography, colour Doppler ultrasonography, and focused helical CT with enteric and/or intravenous contrast. It has even been suggested that all patients with suspected appendicitis should undergo CT scanning (182). Such a strategy can be effective only if the radiological investigations are undertaken rapidly, are interpreted accurately and definitively, and are used to guide treatment. It seems that such high standards could be achieved only in centres in which emergency medicine, radiology and surgery services are well coordinated, and in which equipment and highly trained personnel are committed to the management of appendicitis [206]. Unfortunately, these conditions are difficult to meet.

\section{REFERENCES}

1. Addiss DG, Shaffer N, Fowler BS, Tauxe RV. The epidemiology of appendicitis and appendectomy in the United States. Am J Epidemiol 1990;132:910-25.

2. Korner H, Sondenaa K, Soreide JA, et al. Incidence of acute nonperforated and perforated appendicitis: age-specific and sex-specific analysis. World J Surg 1997;21:313-7.

3. Lund DP, Murphy EU. Management of perforated appendicitis in children: a decade of aggressive treatment. J Pediatr Surg 1994;29:1130-4.

4. Poole GV. Appendicitis. The diagnostic challenge continues. Am Surg 1988;54:609-12.

5. Lewis FR, Holcroft JW, Boey J, Dunphy E. Appendicitis: a critical review of diagnosis and treatment in 1000 cases. Arch Surg 1975;110:677-84.

6. Silberman VA. Appendectomy in a large metropolitan hospital: retrospective analysis of 1,013 cases. Am J Surg 1981;142:615-8.

7. Berry J, Malt RA. Appendicitis near its centenary. Ann Surg 1984;200:567-75.

8. Hale DA, Molloy M, Pearl RH, Schutt DC, Jaques DP. Appendectomy: a contemporary appraisal. Ann Surg 1997;225:252-61.

9. Graff L, Russell J, Seashore J, et al. False-negative and false-positive errors in abdominal pain evaluation: failure to diagnosis acute appendicitis and unnecessary surgery. Acad Emerg Med 2000;7:1244-55.

10. Temple CL, Huchcroft SA, Temple WJ. The natural history of appendicitis in adults: a prospective study. Ann Surg 1995;221:278-81.

11. Von Titte SN, McCabe CJ, Ottinger LW. Delayed appendectomy for appendicitis: causes and consequences. Am J Emerg Med 1996;14:620-2.

12. Andersson RE, Hugander A, Thulin AJG. Diagnostic accuracy and perforation rate in appendicitis: association with age and sex of the patient and with appendicectomy rate. Eur J Surg 1992;158:37-41.

13. Law D, Law R, Eiseman B. The continuing challenge of acute and perforated appendicitis. Am J Surg 1976;131:533-5.

14. Andersen M, Lilja T, Lundell L, Thulin A. Clinical and laboratory findings in patients subjected to laparotomy for suspected acute appendicitis. Acta Chir Scand 1980;146:55-63.

15. Lau W-Y, Fan S-T, Yiu T-F, Chu K-W, Wong S-H. Negative findings at appendectomy. Am J Surg 1984;148:375-8.

16. Chang FC, Hogle HH, Welling DR. The fate of the negative appendix. Am J Surg 1973;126:752-4.

17. Deutsch AA, Shani N, Reiss R. Are some appendectomies unnecessary? An analysis of 319 white appendices. J R Coll Surg Edinb $1983 ; 28: 35-40$

18. Horowitz MD, Gomez GA, Santiesteban R, Burkett G. Acute appendicitis during pregnancy: diagnosis and management. Arch Surg $1985 ; 120: 1362-7$.

19. Vorhes CE. Appendicitis in the elderly: the case for better diagnosis. Geriatrics 1987;42:89-92.

20. Doherty GM, Lewis FR Jr. Appendicitis: continuing diagnostic challenge. Emerg Med Clin North Am 1989;7:537-53.
21. Rappaport WD, Peterson M, Stanton C. Factors responsible for the high perforation rate seen in early childhood appendicitis. Am Surg 1989;55:602-5.

22. Elangovan S. Clinical and laboratory findings in acute appendicitis in the elderly. J Am Board Fam Pract 1996;9:75-8.

23. Tracey M, Fletcher HS. Appendicitis in pregnancy. Am Surg 2000;66:555-9.

24. Thomas EJ, Mueller B. Appendectomy: diagnostic criteria and hospital performance. Hosp Pract 1969;4:72-8.

25. Jess P, Bjerregaard B, Byrnitz S, Holst-Christensen J, Kalaja E, Lund-Kristensen J. Acute appendicitis: prospective trial concerning diagnostic accuracy and complications. Am J Surg 1981;141:232-4.

26. Velanovich V, Satava R. Balancing the normal appendectomy rate with the perforated appendicitis rate: implications for quality assurance. Am Surg 1992;58:264-9.

27. Alvarado A. A practical score for the early diagnosis of acute appendicitis. Ann Emerg Med 1986;15:557-64.

28. Ohmann C, Yang Q, Franke C. Diagnostic scores for acute appendicitis. Abdominal Pain Study Group. Eur J Surg 1995;161:273-81.

29. Bond GR, Tully, Chan LS, Bradley RL. Use of the MANTRELS score in childhood appendicitis: a prospective study of 187 children with abdominal pain. Ann Emerg Med 1990;19:1014-8.

30. Kalan M, Talbot D, Cunliffe WJ, Rich AJ. Evaluation of the modified Alvarado score in the diagnosis of acute appendicitis: a prospective study. Ann R Coll Surg Engl 1994;76:418-9.

31. Macklin CP, Radcliffe GS, Merei JM, Stringer MD. A prospective evaluation of the modified Alvarado score for acute appendicitis in children. Ann R Coll Surg Engl 1997;79:203-5.

32. Talwar S, Talwar R, Prasad P, Malik AA, Wani NA. Continuing diagnostic challenge of acute appendicitis: evaluation through modified Alvarado score. Aust N Z J Surg 1999;69:821-2.

33. Jones PF. Active observation in management of acute abdominal pain in childhood. Br Med J 1976;ii:551-3.

34. Putnam TC, Gagliano N, Emmends RW. Appendicitis in children Surg Gynecol Obstet 1990;170:527-32.

35. Olsen JB, Myren CJ, Haahr PE. Randomized study of the value of laparoscopy before appendicectomy. Br J Surg 1993;80:922-3.

36. Tytgat SH, Bakker XR, Butzelaar RM. Laparoscopic evaluation of patients with suspected acute appendicitis. Surg Endosc 1998;12:918-20.

37. Moberg A-C, Ahlberg G, Leijonmarck C-E, et al. Diagnostic laparoscopy in 1043 patients with suspected acute appendicitis. Eur J Surg 1998;164:833-41.

38. Moberg AC, Montgomery A. Introducing diagnostic laparoscopy for patients with suspected acute appendicitis. Surg Endosc 2000;14:942-7.

39. Van den Broek WT, Bijnen AB, van Eerten PV, de Ruiter P, Gouma DJ. Selective use of diagnostic laparoscopy in patients with suspected appendicitis. Surg Endosc 2000;14:938-41.

40. Wagner M, Aronsky D, Tschudi J, Metzger A, Klaiber C. Laparoscopic stapler appendectomy. A prospective study of 267 consecutive cases. Surg Endosc 1996;10:895-9.

41. Laine S, Rantala A, Gullichsen R, Ovaska J. Laparoscopic appendectomy - Is it worthwhile? A prospective, randomized study in young women. Surg Endosc 1997;11:95-7.

42. Reiertsen O, Larsen S, Trondsen E, Edwin B, Faerden AE, Rosseland AR. Randomized controlled trial with sequential design of laparoscopic versus conventional appendicectomy. Br J Surg 1997;84:842-7.

43. Croce E, Olmi S, Azzola M, Russo R. Laparoscopic appendectomy and minilaparoscopic approach: a retrospective review after 8-years' experience. J Soc Laparoendoscopic Surg 1999;3:285-92.

44. Borgstein PJ, Gordijn RV, Eijsbouts QA, Cuesta MA. Acute appendicitis - A clear-cut case in men, a guessing game in young women. A prospective study on the role of laparoscopy. Surg Endosc 1997;11:923-7.

45. Lamparelli MJ, Hoque HM, Pogson CJ, Ball AB. A prospective evaluation of the combined use of the modified Alvarado score with selective laparoscopy in adult females in the management of suspected appendicitis. Ann R Coll Surg Engl 2000;82:192-5.

46. Larsson PG, Henriksson G, Olsson M, et al. Laparoscopy reduces unnecessary appendicectomies and improves diagnosis in fertile women. A randomized study. Surg Endosc 2001;15:200-2.

47. Grunewald B, Keating J. Should the "normal" appendix be removed at operation for appendicitis? J R Coll Surg Edinb 1993;38:158-60. 
48. Connor TJ, Garcha IS, Ramshaw BJ, et al. Diagnostic laparoscopy for suspected appendicitis. Am Surg 1995;61:187-9.

49. Wilcox RT, Traverso LW. Have the evaluation and treatment of acute appendicitis changed with new technology? Surg Clin North Am 1997;77:1355-70.

50. Lau W-Y, Fan S-T, Yiu T-F, Chu K-W, Suen H-C, Wong K-K. The clinical significance of routine histopathologic study of the resected appendix and safety of appendiceal inversion. Surg Gynecol Obstet $1986 ; 162: 256-8$

51. Jones MW, Paterson MG. The correlation between gross appearance of the appendix at appendicectomy and histological examination. Ann R Coll Surg Engl 1988;70:93-4.

52. Miettinen P, Pasanen P, Lahtinen J, Kosonen P, Alhava E. The longterm outcome after negative appendix operation. Ann Chir Gynaecol 1995;84:267-70.

53. Wang Y, Reen DJ, Puri P. Is a histologically normal appendix following emergency appendicectomy always normal? Lancet 1996;347:1076-9.

54. Di Sebastiano P, Fink T, di Mola FF, et al. Neuroimmune appendicitis. Lancet 1999;354:461-6.

55. Xiong S, Puri P, Nemeth L, O'Briain DS, Reen DJ. Neuronal hypertrophy in acute appendicitis. Arch Pathol Lab Med 2000;124:1429-33.

56. Nemeth L, Reen DJ, O’Brian S, McDermott M, Puri P. Evidence of an inflammatory pathologic condition in "normal" appendices following emergency appendectomy. Arch Pathol Lab Med 2001;125:759-64.

57. Dymock RB. Pathologic changes in the appendix: a review of 1000 cases. Pathology 1977;9:331-9.

58. Grossman EB Jr. Chronic appendicitis. Surg Gynecol Obstet 1978;146:596-8.

59. Savrin RA, Clausen K, Martin EW Jr, Cooperman M. Chronic and recurrent appendicitis. Am J Surg 1979;137:355-7.

60. Crabbe MM, Norwood SH, Robertson HD, Silva JS. Recurrent and chronic appendicitis. Surg Gynecol Obstet 1986;163:11-3.

61. Dickson JA, Jones A, Telfer S, de Dombal FT. Acute abdominal pain in children. Scand J Gastroenterol Suppl 1988;144:43-6.

62. Seidman JD Anderson DK, Ulrich S, Hoy GR, Chun B. Recurrent abdominal pain due to chronic appendiceal disease. South Med J 1991;84:913-6.

63. Hawes AS, Whalen GF. Recurrent and chronic appendicitis: the other inflammatory conditions of the appendix. Am Surg 1994;60:217-9.

64. Fayez JA, Toy NJ, Flanagan TM. The appendix as the cause of chronic lower abdominal pain. Am J Obstet Gynecol $1995 ; 172: 122-3$

65. Gorenstein A, Serour F, Katz R, Usviatsov I. Appendiceal colic in children: a true clinical entity? J Am Coll Surg 1996;182:246-50.

66. Ciani S, Chuaqui B. Histological features of resolving acute, noncomplicated phlegmonous appendicitis. Pathol Res Pract 2000;196:89-93.

67. Soter CS. The contribution of the radiologist to the diagnosis of acute appendicitis. Semin Roentgenol 1973;8:375-88.

68. Bakhda RK, McNair MM. Useful radiologic signs in acute appendicitis in children. Clin Radiol 1977;28:193-6.

69. Bignongiari LR, Wicks JD. Gas-filled appendix with meniscus: outline of the appendolith. Gastrointest Radiol 1978;3:229-231.

70. Baker SB. Acute appendicitis: pain radiographic considerations. Emerg Radiol 1996;3:63-9.

71. Joffe N. Radiology of acute appendicitis and its complications. Crit Rev Clin Radiol Nucl Med 1975;7:97-160.

72. Lee PWR. The plain film in the acute abdomen: a surgeon's evaluation. Br J Surg 1976;63:763-6.

73. Brooks DW Jr, Killen DA. Roentgenographic findings in acute appendicitis. Surgery 1965;57:377-84.

74. Graham AD, Johnson HF. The incidence of radiographic findings in acute appendicitis compared to 200 normal abdomens. Mil Med 1966;131:272-6.

75. Shimkin PM. Radiology of acute appendicitis. Am J Roentgenol 1978;130:1001-4.

76. Simeone JF, Novelline RA, Ferrucci JT Jr, et al. Comparison of sonography and plain films in evaluation of the acute abdomen. AJR Am J Roentgenol 1985;144:49-52.

77. Rao PM, Rhea JT, Rao JA, Conn AK. Plain abdominal radiography in clinically suspected appendicitis: diagnostic yield, resource use, and comparison with CT. Am J Emerg Med 1999;17:325-8.
78. Makanjuola D, Al Qasabi Q, Malabarey T. A comparative ultrasound and plain abdominal $\mathrm{x}$-ray: evaluation of non-classical clinical cases of appendicitis. Ann Saudi Med 1993;13:41-6.

79. Smith DE, Kirchmer NA, Stewart DR. Use of the barium enema in the diagnosis of acute appendicitis and its complications. Am J Surg 1979;138:829-34.

80. Shust N, Blane CE, Oldham KT. Perforation associated with barium enema in acute appendicitis. Pediatr Radiol 1993;23:289-90.

81. Rajagopalan AE, Mason JH, Kennedy M, Pawlikowski J. The value of barium enema in the diagnosis of acute appendicitis. Arch Surg 1977;112:531-3.

82. Fedyshin P, Kelvin FM, Rice RP. Nonspecificity of barium enema findings in acute appendicitis. AJR Am J Roentgenol 1984;143:99-102.

83. El Ferzli G, Ozuner G, Davidson PG, Isenberg JS, Redmond P, Worth MH Jr. Barium enema in the diagnosis of acute appendicitis. Surg Gynecol Obstet 1990;171:40-2.

84. Sakover RP, del Fava RL. Frequency of visualization of the normal appendix with the barium enema examination. Am J Roentgenol Radium Ther Nucl Med 1974;121:312-7.

85. Weigelt J. Diagnosis of appendicitis. In: McClellan RN, Gewertz BL, Fry WJ, eds. Selected Readings in General Surgery, vol 7. Dallas: University of Texas, 1980:1-14.

86. Harding JA, Glick SN, Teplick SK, Kowal L. Appendiceal filling by double-contrast barium enema. Gastrointest Radiol 1986;11:105-7.

87. Rao PM, Boland GWL. Imaging of acute right lower abdominal quadrant pain. Clin Radiol 1998;53:639-49.

88. Hatch EI, Naffis D, Chandler NW. Pitfalls in the use of barium enema in early appendicitis in children. J Pediatr Surg 1981;16:309-12.

89. Homer MJ, Braver JM. Recurrent appendicitis: reexamination of a controversial disease. Gastrointest Radiol 1979;4:295-301.

90. Okamoto T, Utsunomiya T, Inutsuka S, et al. The appearance of a normal appendix on barium enema examination does not rule out a diagnosis of chronic appendicitis: report of a case and review of the literature. Surg Today 1997;27:550-3.

91. Puylaert JBCM. Acute appendicitis: US evaluation using graded compression. Radiology 1986;158:355-60.

92. Birnbaum BA, Wilson SR. Appendicitis at the millennium. Radiology 2000;215:337-48.

93. Pelsang RE, Warnock NG, Abu-Yousef M. Diagnosis of acute appendicitis on transvaginal ultrasonography. J Ultrasound Med 1994;13:723-5.

94. Puylaert JBCM. Transvaginal sonography for diagnosis of appendicitis. AJR Am J Roentgenol 1994;163:746. (Lett)

95. Sivit CJ. Diagnosis of acute appendicitis in children: spectrum of sonographic findings. AJR Am J Roentgenol 1993;161:147-52.

96. Lim H-K, Lee W-J, Lee S-J, Namgung S, Lim J-H. Focal appendicitis confined to the tip: diagnosis at US. Radiology 1996;200:799-801.

97. Šmonovský V. Sonographic detection of normal and abnormal appendix. Clin Radiol 1999;54:533-9.

98. Jeffrey RB Jr, Laing FC, Lewis FR. Acute appendicitis: high-resolution real-time US findings. Radiology 1987;163:11-4.

99. Abu-Yousef MM, Bleicher JJ, Maher JW, Urdaneta LF, Franken EA Jr, Metcalf AM. High-resolution sonography of acute appendicitis. AJR Am J Roentgenol 1987;149:53-8.

100. Borushok KF, Jeffrey RB Jr, Laing FC, Townsend RR. Sonographic diagnosis of perforation in patients with acute appendicitis. AJR Am J Roentgenol 1990;154:275-8.

101. Quillin SP, Siegel MJ, Coffin CM. Acute appendicitis in children: value of sonography in detecting perforation. AJR Am J Roentgenol 1992;159:1265-8.

102. Rettenbacher T, Hollerweger A, Macheiner P, et al. Presence or absence of gas in the appendix: additional criteria to rule out or confirm acute appendicitis - Evaluation with US. Radiology 2000;214:183-7.

103. Puylaert JCBM, Rutgers RB, Lalisang RI, et al. A prospective study of ultrasonography in the diagnosis of appendicitis. N Engl J Med 1987;317:666-9.

104. Jeffrey RB Jr, Laing FC, Townsend RR. Acute appendicitis: sonographic criteria based on 250 cases. Radiology 1988;167:327-9.

105. Skaane P, Amland PF, Nordshus T, Solheim K. Ultrasonography in patients with suspected acute appendicitis: a prospective study. Br J Radiol 1990;63:787-93.

106. Siegel MJ, Carel CC, Surratt S. Ultrasonography of acute abdominal pain in children. JAMA 1991;266:1987-9.

107. Jeffrey RB Jr, Jain KA, Nghiem HV. Sonographic diagnosis of acute appendicitis: interpretive pitfalls. AJR Am J Roentgenol 1994;162:55-9. 
108. Kao SCS, Smith WL, Abu-Yousef MM, et al. Acute appendicitis in children: sonographic findings. AJR Am J Roentgenol 1989;153:375-9.

109. Rettenbacher T, Hollerweger A, Macheiner P, et al. Outer diameter of the vermiform appendix as a sign of acute appendicitis: evaluation at US. Radiology 2001;218:757-62.

110. John $\mathrm{H}$, Neff U, Kelemen M. Appendicitis diagnosis today: clinical and ultrasonic deductions. World J Surg 1993;17:243-9.

111. Ooms HW, Koumans RK, Ho Kang You P-J, Puylaert JBCM. Ultrasonography in the diagnosis of acute appendicitis. Br J Surg 1991;78:315-8.

112. Hayden CK Jr, Kuchelmeister J, Lipscomb TS. Sonography of acute appendicitis in childhood: perforation versus nonperforation. J Ultrasound Med 1992;11:209-16.

113. Ramachandran P, Sivit CJ, Newman KD, Schwartz MZ. Ultrasonography as an adjunct in the diagnosis of acute appendicitis: a 4-year experience. J Pediatr Surg 1996;31:164-7.

114. Hahn HB, Hoepner FU, Kalle T, et al. Sonography of acute appendicitis in children: 7 years experience. Pediatr Radiol 1998;28:147-51.

115. Balthazar EJ, Birnbaum BA, Yee J, Megibow AJ, Roshkow J, Gray C. Acute appendicitis: CT and US correlation in 100 patients. Radiology 1994;190:31-5.

116. Lim HK, Bae SH, Seo GS. Diagnosis of acute appendicitis in pregnant women: value of sonography. AJR Am J Roentgenol 1992;159:539-42.

117. Josephson T, Styrud J, Eriksson S. Ultrasonography in acute appendicitis. Body mass index as selection factor for US examination. Acta Radiol 2000;41:486-8.

118. Wade DS, Marrow SE, Balsara ZN, Burkhard TK, Goff WB. Accuracy of ultrasound in the diagnosis of acute appendicitis compared with the surgeon's clinical impression. Arch Surg 1993;128:1039-44

119. Zielke A, Hasse C, Sitter H, Kisker O, Rothmund M. "Surgical" ultrasound in suspected acute appendicitis. Surg Endosc 1997;11:362-5.

120. Zielke A, Hasse C, Sitter H, Rothmund M. Influence of ultrasound on clinical decision making in acute appendicitis: a prospective study. Eur J Surg 1998;164:201-9.

121. Galindo Gallego M, Fadrique B, Nieto MA, et al. Evaluation of ultrasonography and clinical diagnostic scoring in suspected appendicitis. Br J Surg 1998;85:37-40.

122. Lessin MS, Chan M, Catallozzi M, et al. Selective use of ultrasonography for acute appendicitis in children. Am J Surg 1999;177:193-6.

123. Chen S-C, Wang H-P, Hsu H-Y, Huang P-M, Lin F-Y. Accuracy of ED sonography in the diagnosis of acute appendicitis. Am J Emerg Med 2000;18:449-52.

124. Jahn H, Mathiesen FK, Neckelmann K, Hovendal CP, Bellstrom T, Gottrup F. Comparison of clinical judgment and diagnostic ultrasonography in the diagnosis of acute appendicitis: experience with a score-aided diagnosis. Eur J Surg 1997;163:433-43.

125. Douglas CD, Macpherson NE, Davidson PM, Gani JS. Randomised controlled trial of ultrasonography in diagnosis of acute appendicitis, incorporating the Alvarado score. Br Med J 2000;321:919-22.

126. Drinkovic I, Brkljacic B, Odak D, Hebrang A. Value of ultrasound in the diagnosis of acute appendicitis. Radiol Oncol 1995;29:190-3.

127. Garcia-Aguayo FJ, Gil P. Sonography in acute appendicitis: diagnostic utility and influence upon management and outcome. Eur Radiol 2000;10:1886-93.

128. Zielke A, Sitter H, Rampp T, Bohrer T, Rothmund M. Clinical decision-making, ultrasonography, and scores for evaluation of suspected acute appendicitis. World J Surg 2001;25:578-84

129. Chesbrough RM, Burkhard TK, Balsara ZN, Goff WB, Davis DJ. Self-localization in US of appendicitis: an addition to graded compression. Radiology 1993;187:349-51.

130. Soda K, Nemoto K, Yoshizawa S, Hibiki T, Shizuya K, Konishi F Detection of pinpoint tenderness on the appendix under ultrasonography is useful to confirm acute appendicitis. Arch Surg 2001;136:1136-40

131. Dilley A, Wesson D, Munden M, Hicks J, Brandt M, Minifee P, Nuchtern J. The impact of ultrasound examinations on the management of children with suspected appendicitis: a 3-year analysis. J Pediatr Surg 2001;36:303-8.

132. Yacoe ME, Jeffrey RB Jr. Sonography of appendicitis and diverticulitis. Radiol Clin North Am 1994;32:899-912.
133. Verroken R, Penninckx F, Van Hoe L, Marchal G, Geboes K, Kerremans R. Diagnostic accuracy of ultrasonography and surgical decision-making in patients referred for suspicion of appendicitis. Acta Chir Belg 1996;96:158-60.

134. Skaane P, Schistad O, Amland PF, Solheim K. Routine ultrasonography in the diagnosis of acute appendicitis: a valuable tool in daily practice? Am Surg 1997;63:937-42.

135. Pohl D, Golub R, Schwartz GE, Stein HD. Appendiceal ultrasonography performed by nonradiologists: does it help in the diagnostic process? J Ultrasound Med 1998;17:217-21.

136. Styrud J, Eriksson S, Segelman J, Granström L. Diagnostic accuracy in 2,351 patients undergoing appendicectomy for suspected acute appendicitis: a retrospective study 1986-1993. Dig Surg 1999;16:39-44.

137. Herd ME, Cross PA, Dutt S. Histological audit of acute appendicitis. J Clin Pathol 1992;45:456-8.

138. Davies AH, Mastorakou I, Cobb R, Rogers C, Lindsell D, Mortensen NJ. Ultrasonography in the acute abdomen. Br J Surg 1991;78:1178-80

139. Beasley SW. Can we improve diagnosis of acute appendicitis? Ultrasonography may complement clinical assessment in some patients. Br Med J 2000;321:907-8.

140. Schwerk WB, Wichtrup B, Ruschoff J, Rothmund M. Acute and perforated appendicitis: current experience with ultrasound-aided diagnosis. World J Surg 1990;14:271-6.

141. Sivit CJ, Newman KD, Boenning DA, et al. Appendicitis: usefulness of US in diagnosis in a pediatric population. Radiology 1992;185:549-52.

142. Kang W-M, Lee C-H, Chou Y-H, et al. A clinical evaluation of ultrasonography in the diagnosis of acute appendicitis. Surgery 1989;105:154-9

143. Larson JM, Peirce JC, Ellinger DM, et al. The validity and utility of sonography in the diagnosis of appendicitis in the community setting. AJR Am J Roentgenol 1989:153:687-91.

144. Orr RK, Porter D, Hartman D. Ultrasonography to evaluate adults for appendicitis: decision making based on meta-analysis and probabilistic reasoning. Acad Emerg Med 1995;2:644-50.

145. Ford RD, Passinault WJ, Morse ME. Diagnostic ultrasound for suspected appendicitis: does the added cost produce a better outcome? Am Surg 1994;60:895-8.

146. Axelrod DA, Sonnad SS, Hirschl RB. An economic evaluation of sonographic examination of children with suspected appendicitis. J Pediatr Surg 2000;35:1236-41.

147. Fujii Y, Hata J, Futagami K, et al. Ultrasonography improves diagnostic accuracy of acute appendicitis and provides cost savings to hospitals in Japan. J Ultrasound Med 2000;19:409-14.

148. Wise SW, Labuski MR, Kasales CJ, et al. Comparative assessment of CT and sonographic techniques for appendiceal imaging. AJR Am J Roentgenol 2001;176:933-41.

149. Puylaert JBCM, Rijke AM. An inflamed appendix at sonography when symptoms are improving: to operate or not to operate? Radiology 1997;205:41-2.

150. Migraine S, Atri M, Bret PM, Lough JO, Hinchey JE. Spontaneously resolving acute appendicitis: clinical and sonographic documentation. Radiology 1997;205:55-8.

151. Quillin SP, Siegel MJ. Appendicitis in children: color Doppler sonography. Radiology 1992;184:745-7.

152. Quillin SP, Siegel MJ. Diagnosis of appendiceal abscess in children with acute appendicitis: value of color Doppler sonography. AJR Am J Roentgenol 1995;164:1251-4.

153. Lim H-K, Lee W-J, Kim T-H, Namgung S, Lee S-J, Lim J-H. Appendicitis: usefulness of color Doppler US. Radiology 1996;201:221-5.

154. Patriquin HB, Garcier JM, Lafortune M, et al. Appendicitis in children and young adults: Doppler sonographic-pathologic correlation. AJR Am J Roentgenol 1996;166:629-33.

155. Gutierrez CJ, Mariano MC, Faddis DM, et al. Doppler ultrasound accurately screens patients with appendicitis. Am Surg 1999;65:1015-7.

156. Quillin SP, Siegel MJ. Appendicitis: efficacy of color Doppler sonography. Radiology 1994;191:557-60.

157. Pinto F, Lencioni R, Falleni A, et al. Assessment of hyperemia in acute appendicitis: comparison between power Doppler and color Doppler sonography. Emerg Radiol 1998;5:92-6.

158. Sivit CJ, Applegate KE, Stallion A, et al. Imaging evaluation of suspected appendicitis in a pediatric population: 
effectiveness of sonography versus CT. AJR Am J Roentgenol 2000;175:977-80.

159. Stroman DL, Bayouth CV, Kuhn JA, et al. The role of computed tomography in the diagnosis of acute appendicitis. Am J Surg 1999; $178: 485-9$

160. Horton MD, Counter SF, Florence MG, Hart MJ. A prospective trial of computed tomography and ultrasonography for diagnosing appendicitis in the atypical patient. Am J Surg 2000;179:379-81.

161. Pickuth D, Heywang-Kobrunner SH, Spielmann RP. Suspected acute appendicitis: is ultrasonography or computed tomography the preferred imaging technique? Eur J Surg 2000;166:315-9.

162. Garcia Peña BM, Mandl KD, Kraus SJ, et al. Ultrasonography and limited computed tomography in the diagnosis and management of appendicitis in children. JAMA 1999;282:1041-6.

163. Fefferman NR, Roche KJ, Pinkney LP, Ambrosino MM, Genieser NB. Suspected appendicitis in children: focused CT technique for evaluation. Radiology 2001;220:691-5.

164. Garcia Peña BM, Taylor GA. Radiologists' confidence in interpretation of sonography and CT in suspected pediatric appendicitis. AJR Am J Roentgenol 2000;175:71-4.

165. Birnbaum BA, Balthazar EJ. CT of appendicitis and diverticulitis. Radiol Clin North Am 1994:32:885-98.

166. Rao PM, Rhea JT, Novelline RA. Appendiceal and peri-appendiceal air at CT: prevalence, appearance and clinical significance. Clin Radiol 1997;52:750-4.

167. Rao PM, Rhea JT, Novelline RA. Sensitivity and specificity of the individual CT signs of appendicitis: experience with 200 helical appendiceal CT examinations. J Comput Assist Tomogr 1997;21:686-92.

168. Malone AJ Jr, Wolf CR, Malmed AS, Melliere BF. Diagnosis of acute appendicitis: value of unenhanced CT. AJR Am J Roentgenol $1993 ; 160: 763-6$

169. Curtin KR, Fitzgerald SW, Nemcek AA Jr, Hoff FL, Vogelzang RL. CT diagnosis of acute appendicitis: imaging findings. AJR Am J Roentgenol 1995;164:905-9.

170. Zeman RK, Baron RL, Jeffrey RB Jr, Klein J, Siegel MJ, Silverman PM. Helical body CT: evolution of scanning protocols. AJR Am J Roentgenol 1998;170:1427-38.

171. Rao PM, Rhea JT, Novelline RA. Helical CT of appendicitis and diverticulitis. Radiol Clin North Am 1999;37:895-910.

172. Jacobs JE, Birnbaum BA, Macari M, et al. Acute appendicitis: comparison of helical CT diagnosis focused technique with oral contrast material versus nonfocused technique with oral and intravenous contrast material. Radiology 2001;220:683-90.

173. Weltman DI, Yu J, Krumenacker J Jr, Huang S, Moh P. Diagnosis of acute appendicitis: comparison of 5- and 10-mm CT sections in the same patient. Radiology 2000;216:172-7.

174. Mindelzun RD, Jeffrey RB Jr. Unenhanced helical CT for evaluating acute abdominal pain: a little more cost, a lot more information. Radiology 1997;205:43-5.

175. Seltzer SE. Answer to question: "Are there clear indications for using helical, as opposed to standard, CT?" AJR Am J Roentgenol 1995;164:1548-9.

176. Balthazar EJ, Megibow AJ, Siegel SE, Birnbaum BA. Appendicitis: prospective evaluation with high-resolution CT. Radiology 1991;180:21-4.

177. Weyant MJ, Eachempati SR, Maluccio MA, et al. Interpretation of computed tomography does not correlate with laboratory or pathologic findings in surgically confirmed acute appendicitis. Surgery 2000;128:145-52.

178. Sivit CJ, Dudgeon DL, Applegate KE, et al. Evaluation of suspected appendicitis in children and young adults: helical CT. Radiology 2000;216:430-3.

179. Kamel IR, Goldberg SN, Keogan MT, Rosen MP, Raptopoulos V. Right lower quadrant pain and suspected appendicitis: nonfocused appendiceal CT - A review of 100 cases. Radiology 2000;217:159-63.

180. Peck J, Peck A, Peck C, Peck J. The clinical role of noncontrast helical computed tomography in the diagnosis of acute appendicitis. Am J Surg 2000;180:133-6.

181. Mullins ME, Kircher MF, Ryan DP, et al. Evaluation of suspected appendicitis in children using limited helical CT and colonic contrast material. AJR Am J Roentgenol 2001;176:37-41.

182. Rao PM, Rhea JT, Novelline RA, Mostafavi AA, McCabe CJ. Effect of computed tomography of the appendix on treatment of patients and use of hospital resources. N Engl J Med $1998 ; 338: 141-6$
183. Rao PM, Rhea JT, Rattner DW, Venus LG, Novelline RA. Introduction of appendiceal CT: impact on negative appendectomy and appendiceal perforation rates. Ann Surg 1999;229:344-9.

184. Schuler JG, Shortsleeve MJ, Goldenson RS, Perez-Rossello JM, Perlmutter RA, Thorsen A. Is there a role for abdominal computed tomographic scans in appendicitis? Arch Surg 1998;133:373-6.

185. Balthazar EJ, Rofsky NM, Zucker R. Appendicitis: the impact of computed tomography imaging on negative appendectomy and perforation rates. Am J Gastroenterol 1998;93:768-71.

186. Applegate KE, Sivit CJ, Salvator AE, et al. Effect of cross-sectional imaging on negative appendectomy and perforation rates in children. Radiology 2001;220:103-7.

187. Wilson EB, Cole JC, Nipper ML, Cooney DR, Smith RW. Computed tomography and ultrasonography in the diagnosis of appendicitis: when are they indicated? Arch Surg 2001;136:670-5.

188. Karakas SP, Guelfguat M, Leonidas JC, Springer S, Singh SP. Acute appendicitis in children: comparison of clinical diagnosis with ultrasound and CT imaging. Pediatr Radiol 2000;30:94-8.

189. Walker S, Haun W, Clark J, McMillin K, Zeren F, Gilliland T. The value of limited computed tomography with rectal contrast in the diagnosis of acute appendicitis. Am J Surg 2000;180:450-4.

190. Rhea JT, Rao PM, Novelline RA, McCabe CJ. A focused appendiceal CT technique to reduce the cost of caring for patients with clinically suspected appendicitis. AJR Am J Roentgenol 1997;169:113-8.

191. Garcia Peña BM, Taylor GA, Lund DP, Mandl KD. Effect of computed tomography on patient management and costs in children with suspected appendicitis. Pediatrics 1999;104:440-6.

192. Garcia Peña BM, Taylor GA, Fishman SJ, Mandl KD. Costs and effectiveness of ultrasonography and limited computed tomography for diagnosing appendicitis in children. Pediatrics 2000;106:672-6.

193. Kanegaye JT, Vance CW, Parisi M, et al. Failure of technetium-99m hexamethylpropylene amine oxime leukocyte scintigraphy in the evaluation of children with suspected appendicitis. Pediatr Emerg Care 1995;11:285-90.

194. Kipper SL, Rypins EB, Evans DG, Thakur ML, Smith TD, Rhodes B. Neutrophil-specific $99 \mathrm{mTc}$-labeled anti-CD15 monoclonal antibody imaging for diagnosis of equivocal appendicitis. J Nucl Med 2000;41:449-55

195. Rypins EB, Kipper SL. Scintigraphic determination of equivocal appendicitis. Am Surg 2000;66:891-5.

196. Barron B, Hanna C, Passalaqua AM, Lamki L, Wegener WA, Goldenberg DM. Rapid diagnostic imaging of acute, nonclassic appendicitis by leukoscintigraphy with sulesomab, a technetium 99 m-labeled antigranulocyte antibody Fab' fragment. LeukoScan Appendicitis Clinical Trial Group. Surgery 1999;125:288-96.

197. Biersack HJ, Overbeck B, Ott G, et al. Tc-99m labeled monoclonal antibodies against granulocytes (BW 250/183) in the detection of appendicitis. Clin Nucl Med 1993;18:371-6.

198. Wong D-W, Vasinrapee P, Spieth ME, et al. Rapid detection of acute appendicitis with Tc-99m-labeled intact polyvalent human immune globulin. J Am Coll Surg 1997;185:534-43.

199. Varoglu E, Polat KY, Tastekin G, Akcay F, Polat C. Diagnostic value of Tc-99m HIG scintigraphy in the detection of acute appendicitis. Clin Nucl Med 1996;21:645-7.

200. Turan C, Tutus A, Ozokutan BH, Yolcu T, Kose O, Kucukaydin M. The evaluation of technetium $99 \mathrm{~m}$-citrate scintigraphy in children with suspected appendicitis. J Pediatr Surg 1999;34:1272-5.

201. Henneman PL, Marcus CS, Butler JA, Freedland ES, Wilson SE, Rothstein RJ. Appendicitis: evaluation by Tc-99m leukocyte scan. Ann Emerg Med 1988;17:111-6.

202. Henneman PL, Marcus CS, Inkelis SH, Butler JA, Baumgartner FJ. Evaluation of children with possible appendicitis using technetium 99m leukocyte scan. Pediatrics 1990;85:838-43.

203. Navarro DA, Weber PM, Kang IY, dos Remedios LV, Jasko JA, Sawicki JE. Indium-111 leukocyte imaging in appendicitis. AJR Am J Roentgenol 1987;148:733-6.

204. Incesu L, Coskun A, Selcuk MB, Akan H, Sozubir S, Bernay F. Acute appendicitis: MR imaging and sonographic correlation. AJR Am J Roentgenol 1997;168:669-74.

205. Hörmann M, Paya K, Eibenberger K, et al. MR imaging in children with nonperforated acute appendicitis: value of unenhanced MR imaging in sonographically selected cases. AJR Am J Roentgenol 1998; 171:467-70. 
206. Novelline RA, Rhea JT, Rao PM, Stuk JL. Helical CT in emergency radiology. Radiology 1999;213:321-39.

207. Vignault F, Filiatrault D, Brandt ML, Garel L, Grignon A, Quimet A. Acute appendicitis in children: evaluation with US. Radiology 1990;176:501-4.

208. Rioux M. Sonographic detection of the normal and abnormal appendix. AJR Am J Roentgenol 1992;158:773-8.

209. Chen S-C, Chen K-M, Wang S-M, Chang K-J. Abdominal sonography screening of clinically diagnosed or suspected appendicitis before surgery. World J Surg 1998;22:449-52.

210. Schulte B, Beyer D, Kaiser C, Horsch S, Wiater A. Ultrasonography in suspected acute appendicitis in childhood - Report of 1285 cases. Eur J Ultrasound 1998;8:177-82.

211. Rao PM, Rhea JT, Novelline RA, et al. Helical CT technique for the diagnosis of appendicitis: prospective evaluation of a focused appendix CT examination. Radiology 1997;202:139-44.

212. Rao PM, Rhea JT, Novelline RA, Mostafavi AA, Lawrason JN, McCabe CJ. Helical CT combined with contrast material administered only through the colon for imaging of suspected appendicitis. AJR Am J Roentgenol 1997;169:1275-80.

213. Lane MJ, Katz DS, Ross BA, et al. Unenhanced helical CT for suspected acute appendicitis. AJR Am J Roentgenol 1997;168:405-9.

214. Funaki B, Grosskreutz SR, Funaki CN. Using unenhanced helical CT with enteric contrast material for suspected appendicitis in patients treated at a community hospital. AJR Am J Roentgenol 1998;171:997-1001.

215. Lane MJ, Liu DM, Huynh MD, Jeffrey RB Jr, Mindelzun RE, Katz DS. Suspected acute appendicitis: nonenhanced helical CT in 300 consecutive patients. Radiology 1999;213:341-6.

216. Foley CR, Latimer RG, Rimkus DS. Detection of acute appendicitis by technetium 99 HMPAO scanning. Am Surg 1992;58:761-5.

217. Evetts BK, Foley CR, Latimer RG, Rimkus DS. Tc-99 hexamethylpropyleneamineoxide scanning for the detection of acute appendicitis. J Am Coll Surg 1994;179:197-201.

218. Kao C-H, Lin H-T, Wang Y-L, Wang S-J, Liu T-J. Tc-99m HMPAOlabeled WBC scans to detect appendicitis in women. Clin Nucl Med 1996;21:768-71.

219. Lin W-Y, Kao C-H, Lin H-T, Wang Y-L, Wang S-J, Liu T-J. 99Tcm-HMPAO-labelled white blood cell scans to detect acute appendicitis in older patients with an atypical clinical presentation. Nucl Med Commun 1997;18:75-8.

220. Rypins EB, Kipper SL. 99mTc-hexamethylpropyleneamine oxime (Tc-WBC) scan for diagnosing acute appendicitis in children. Am Surg 1997;63:878-81.

221. Kipper SL. The role of radiolabeled leukocyte imaging in the management of patients with acute appendicitis. Q J Nucl Med 1999;43:83-92. 


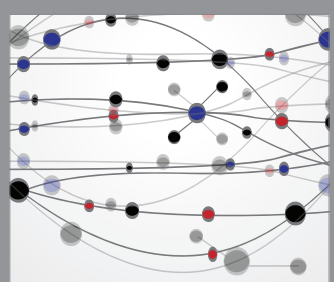

The Scientific World Journal
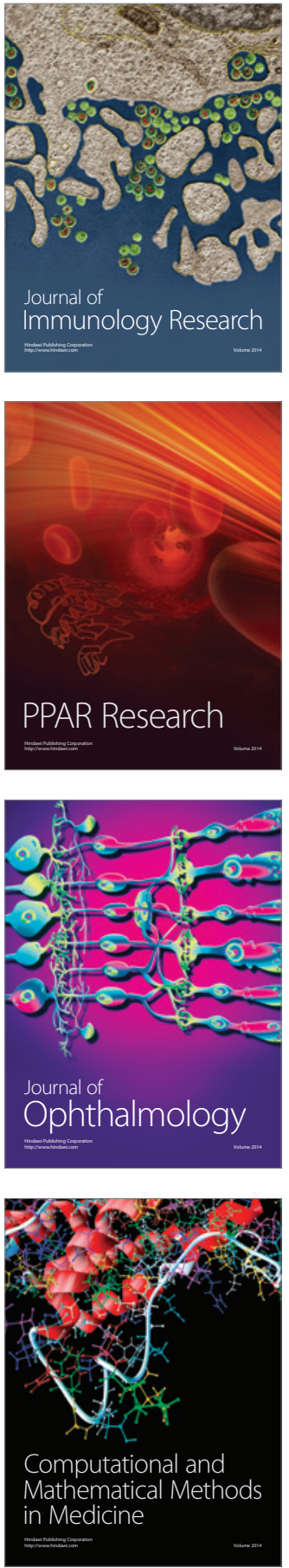

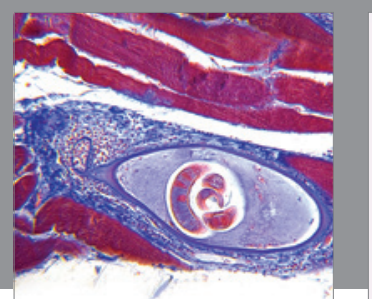

Gastroenterology Research and Practice

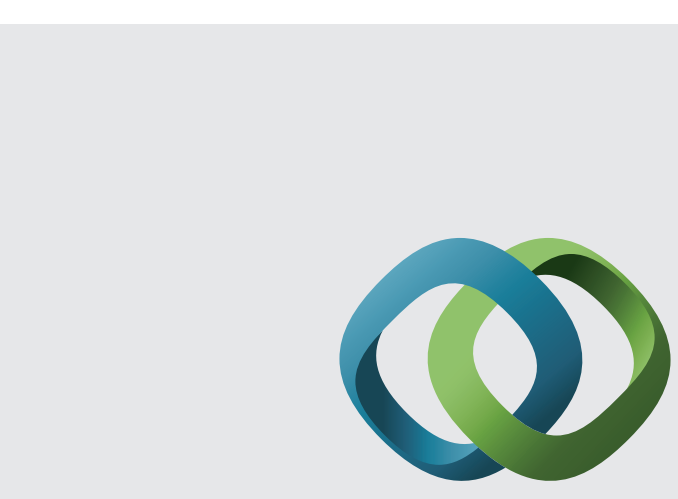

\section{Hindawi}

Submit your manuscripts at

http://www.hindawi.com
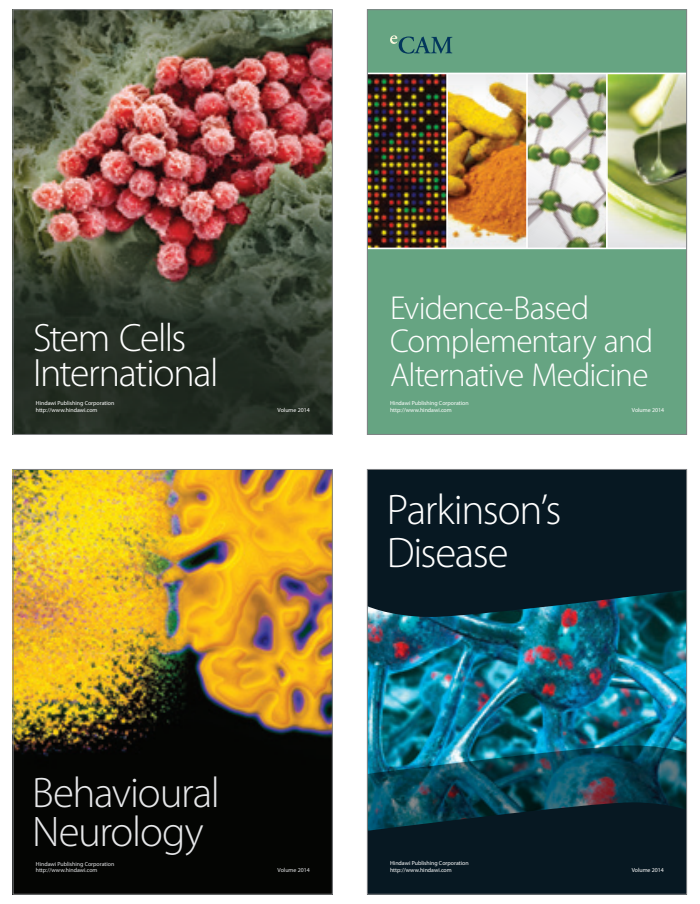
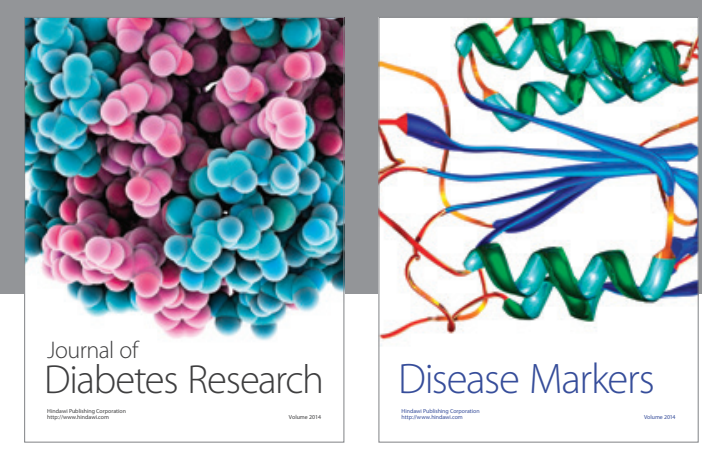

Disease Markers
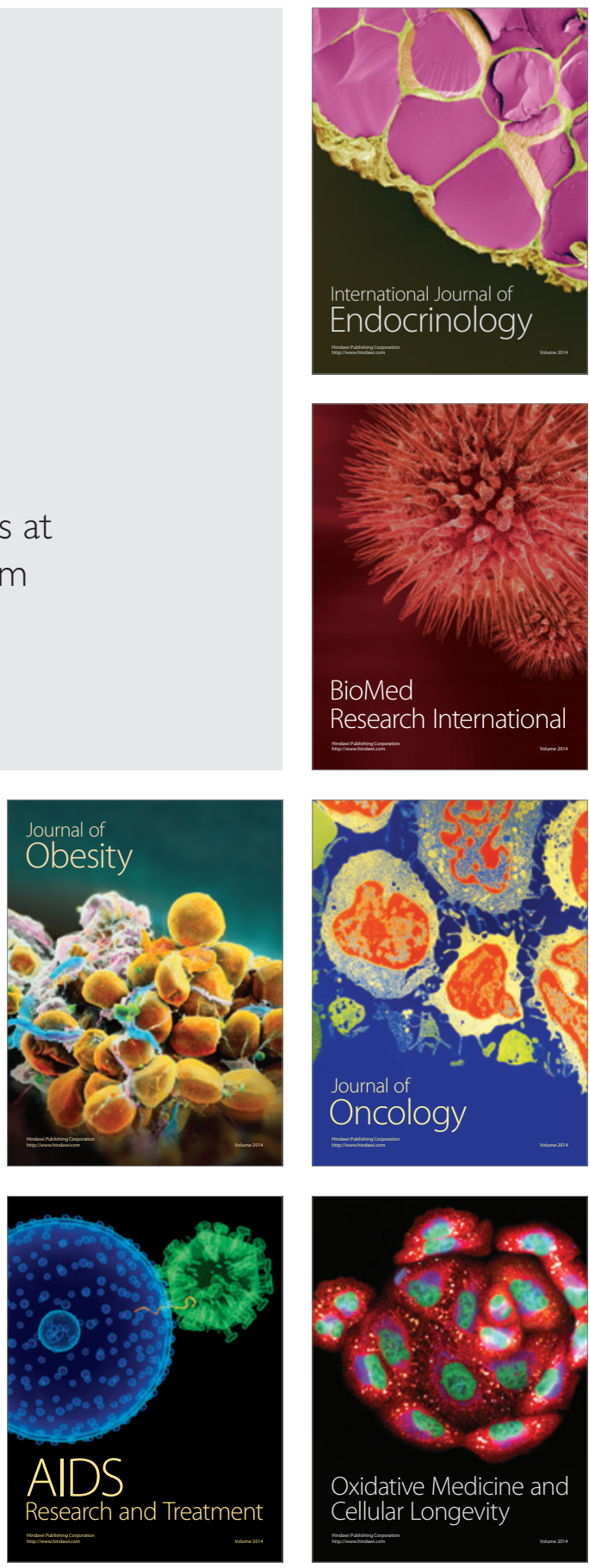